\title{
Thought and Language
}

\author{
Edited by Fohn Preston
}

\author{
ROYAL INSTITUTE OF PHILOSOPHY
}

SUPPLEMENT: 42

The relationship between thought and language has been of central importance to philosophy ever since Plato characterised thinking as 'a dialogue the soul has with itself. In this volume, several major twentieth-century philosophers of mind and language make further contributions to the debate. Among the questions addressed are: Is language conceptually prior to thought, or vice versa? Must thought take place 'in' a medium? To what extent can creatures without language be credited with thoughts? Do we have to suppose that thinking involves the use of concepts? What does it mean to have and deploy a concept? How do recent psychological experiments bear on these issues? Are beliefs, desires, hopes and fears rightly construed as 'attitudes towards propositions'? Should twentiethcentury philosophy be conceived of in terms of Michael Dummett's distinction between 'analytical philosophy' and the 'philosophy of thought'?

\section{Contributors}

Donald Davidson, John Cottingham, John Hyman, Andrew Woodfield, John R. Searle, L. Weiskrantz, Hans-Johann Glock, W. V. Quine, K. V. Wilkes, Christopher Hookway, Daniel C. Dennett

Front cover illustration: from Lycosthenes' Prodigiorum (as appeared on p. 70 of 'Allegory and the Migration of Symbols' by Rudolf Wittrower. London: Thames \& Hudson 1977) 